\title{
Induction of plasma LH surges and normal luteal function in acyclic post-partum ewes by the pulsatile administration of LH-RH
}

\author{
P. J. Wright, P. E. Geytenbeek*, I. J. Clarke† and J. K. Findlay† \\ Department of Veterinary Clinical Sciences, University of Melbourne, Werribee, Victoria 3030 ; \\ *Waite Agricultural Research Institute, Adelaide, South Australia 5064, and †Medical Research \\ Centre, Prince Henry's Hospital, Melbourne, Victoria 3003, Australia
}

\begin{abstract}
Summary. Plasma LH surges, similar to preovulatory surges in cyclic ewes $(N=9)$, were induced in 11/15 acyclic ewes, 19-26 days post partum, treated with LH-RH (100 ng i.v. every $3 \mathrm{~h}$ for $24 \mathrm{~h}$, every $2 \mathrm{~h}$ for $24 \mathrm{~h}$, then every $1 \mathrm{~h}$ for $24 \mathrm{~h}$ ) (Group PPrh), and in 11/15 LH-RH-treated acyclic ewes pretreated with progesterone (s.c. implant for 11 days) (Group PPprh). Plasma progesterone, indicating subsequent luteal function, was detected in 10/11 Group PPrh ewes and in 9/11 Group PPprh ewes. The mean and peak plasma progesterone concentrations in these ewes were similar to those in cyclic ewes $(2.0 \pm 0.2$ and $3.1 \pm 0.4 \mathrm{ng} / \mathrm{ml})$. The periods over which plasma progesterone was detected were similar in cyclic (11.7 \pm 0.5 days) and in Group PPprh ewes $(12.2 \pm 0.8$ days), but less in Group PPrh ewes $(9.6 \pm 0.4$ days). After regression of the induced corpus luteum more Group PPprh ewes (6/9) than Group PPrh ewes (2/10) showed oestrus and continued cycling. These results show that an appropriate pattern of pulsatile LH-RH treatment of post-partum acyclic ewes, pretreated with progesterone, can lead to plasma LH surges, luteal function, and subsequent ovarian cyclicity similar to that found in cyclic ewes. This suggests that ovarian acyclicity in post-partum ewes is a reflection of an inadequate pattern of pulsatile release of $\mathrm{LH}-\mathrm{RH}$ from the hypothalamus.
\end{abstract}

\section{Introduction}

We have suggested that ovarian acyclicity in post-partum ewes results from inadequate release of LH-RH from the hypothalamus (Wright, Geytenbeek, Clarke \& Findlay, 1981). Although the administration of LH-RH in a pulsatile regimen ( $100 \mathrm{ng}$ i.v. every hour for $48 \mathrm{~h}$ ) to acyclic postpartum ewes resulted in plasma LH surges similar to preovulatory LH surges in cyclic ewes, subsequent luteal function was deficient (Wright et al., 1983b). Comparison of the patterns of release of LH induced in post-partum ewes with the patterns occurring naturally in cyclic ewes suggested that the deficient luteal function could have been due to an inadequate duration of increased plasma LH concentrations before the plasma LH surge. This inadequate duration of increased plasma LH concentrations could have been the result of an inappropriate LH-RH treatment regimen, or a lack of progesterone influence before LH-RH treatment. Progesterone pretreatment prolonged the duration of increased plasma $\mathrm{LH}$ concentrations in LH-RH-treated seasonally anoestrous ewes by delaying the plasma LH surge, resulting in subsequent normal luteal function (McLeod, Haresign \& Lamming, 1982). We have therefore studied the effect of a revised pulsatile LH-RH treatment regimen, with and without progesterone pretreatment, in acyclic postpartum ewes. The occurrence of plasma LH surges, subsequent luteal function and ovarian cyclicity were assessed. 


\section{Materials and Methods}

Animals. Fifty mature anoestrous Merino ewes (Bungaree Strain) lambing in April (autumn) and 10 cyclic multiparous ewes from the same flock were studied at the Mortlock Experiment Station near Clare, South Australia from May to August 1981. The post-partum ewes had lambed 19-26 days before the start of treatments with LH-RH or with the vehicle, and each ewe suckled 1 lamb for the duration of the study. The cyclic ewes had not lambed for at least 9 months. Vasectomized rams fitted with 'Sire-sine' harnesses and raddles were kept with the ewes from the start of lambing until 91 days after treatment with LH-RH or vehicle. The teaser rams were not with the ewes during the period of treatment (Day 1 to Day 4) when the ewes were penned in a shed. Daily observations were made to record those ewes in oestrus. During the 4 weeks before treatment the cyclic ewes exhibited regular oestrous cycles, but no oestrous activity was detected in the post-partum ewes.

Treatments and blood sampling. The pulsatile administration of LH-RH or of vehicle commenced at $0 \mathrm{~h}$ on Day 1, when the acyclic ewes were 19-26 days post partum. A summary of the treatment groups is presented in Table 1 . The cyclic control ewes $(\mathbf{N}=10)$ were given $125 \mu \mathrm{g}$ cloprostenol (Estrumate, I.C.I., Australia) i.m. on Day - 13 (Group Cv). Twenty-five acyclic ewes received one progesterone implant (Sil-Estrus; Ceva Chemicals, Australia) s.c. in the axilla region on Day - 11 (Groups PPp and PPprh). The implants were removed on Day 1 between 00:00 and $00: 30 \mathrm{~h}$.

The ewes were placed in the sheep shed at $12: 00 \mathrm{~h}$ on Day -1 . One jugular vein of each ewe was cannulated during the period 15:00 to $18: 00 \mathrm{~h}$.

All of the ewes were treated with cloprostenol on Day 1, between $00: 00$ and $00: 30 \mathrm{~h}$, followed by LH-RH (Groups PPrh and PPprh) or by vehicle (Groups Cv, PPv and PPp). Treatment with LH-RH (Lutal: Hoechst, A.G. West Germany; $100 \mathrm{ng}$ in $2 \mathrm{ml}$ vehicle $(0 \cdot 154 \mathrm{M}-\mathrm{NaCl}, 0 \cdot 1 \% \mathrm{w} / \mathrm{v}$ gelatin)) or with vehicle was by rapid injection via a jugular venous cannula. Injections were given every $3 \mathrm{~h}$ for $24 \mathrm{~h}$, then every $2 \mathrm{~h}$ for $24 \mathrm{~h}$, and then each hour for $24 \mathrm{~h}$.

Blood samples $(8 \mathrm{ml})$ for $\mathrm{LH}$ determination were withdrawn through the jugular venous cannulae from all ewes every $3 \mathrm{~h}$ from 0 to $96 \mathrm{~h}$. When scheduled at the same time, blood samples were taken just before the injection of LH-RH or of vehicle. Blood samples $(8 \mathrm{ml})$ for progesterone determination were taken by jugular venepuncture from Groups PPp and PPprh just before progesterone implant placement, and at $0 \mathrm{~h}$ from all other ewes to confirm reproductive status. Blood samples for progesterone determination were also taken from all ewes on Days 7, 9, 11, 14, $16,18,21$ and 23 to assess luteal function.

Hormone assays. Plasma LH levels were measured in a double-antibody radioimmunoassay (Wright et al., 1980). The standard was NIH-LH-S18 (biopotency $1.03 \times \mathrm{NIH-LH-S1).} \mathrm{Hormone}$ concentrations and assay quality control data were calculated using the methods and computer programme of Burger, Lee \& Rennie (1972). The study included 5 assays with sensitivity $0.4 \mathrm{ng} / \mathrm{ml}$. The inter-assay coefficients of variation $(\mathrm{CV})$ were 16 and $10 \%$ for plasma pools of 3.3 and 55 $\mathrm{ng} / \mathrm{ml}$. The intra-assay $\mathrm{CV}$ was $<20 \%$ over the range 1.5 to $98.0 \mathrm{ng} / \mathrm{ml}$. Samples with $\mathrm{LH}$ values above this range were diluted 1:10 in assay buffer and reassayed. Samples with LH values reflecting $\mathrm{LH}$ surges were reassayed in a single assay.

Plasma progesterone levels were determined by radioimmunoassay in 13 assays (Hossain, Lee, Clarke \& O'Shea, 1979). The sensitivity of the assay was $0.2 \mathrm{nmol} / 1$. The interassay CVs were $10 \%$ and $12 \%$ for plasma pools of 9.8 and $3.8 \mathrm{nmol} / \mathrm{l}$. The intra-assay CV was $<10 \%$ over the range 3-155 nmol/l.

Analysis of results. The progesterone concentrations in plasma of ewes in Groups PPp and PPprh on Day - 11 (progesterone-treated post-partum ewes) and in Groups PPv and PPrh on Day 1 (post-partum ewes not treated with progesterone) were $<0.1 \mathrm{ng} / \mathrm{ml}$, confirming the acyclic status of these ewes. 
A plasma LH surge similar to a naturally occurring preovulatory LH surge was considered to have occurred if plasma LH levels were $>10 \mathrm{ng} / \mathrm{ml}$ for $>6 \mathrm{~h}$. The time of the onset of the LH surge was when plasma $\mathrm{LH}$ was $>10 \mathrm{ng} / \mathrm{ml}$, the end was when $\mathrm{LH}$ values had returned to $<10 \mathrm{ng} / \mathrm{ml}$. These times were estimated by interpolation. The duration of the surge was the period during which plasma $\mathrm{LH}$ levels exceeded $10 \mathrm{ng} / \mathrm{ml}$.

Student's $t$ tests and $\chi^{2}$ tests were used as indicated. All values are presented as means \pm s.e.m.

\section{Results}

Ewes in Group PPprh showed oestrus earlier $(P<0 \cdot 01, t=3 \cdot 2)$, had a shorter $(P<0 \cdot 01, t=3 \cdot 1)$ interval from parturition to first detected oestrus and a greater $(P<0.05, t=2 \cdot 2)$ number of oestrous periods during the 91-day observation period after treatment, than did vehicle-treated post-partum ewes (Group PPv) (Table 1). Treatment of post-partum ewes with progesterone alone (Group PPp) or with LH-RH alone (Group PPrh) did not affect the occurrence of oestrus.

Table 1. The occurrence of oestrus in post-partum and in control cyclic ewes on Days 5-91 after treatment with cloprostenol $(125 \mu \mathrm{g}$ i.m.) on Day 1 between $00: 00$ and $00: 30 \mathrm{~h}$

\begin{tabular}{|c|c|c|c|c|c|}
\hline & \multirow{2}{*}{$\frac{\text { Cyclic ewes }}{\text { Group Cv }}$} & \multicolumn{4}{|c|}{ Post-partum ewes } \\
\hline & & Group PPv & Group $P P p$ & Group PPrh & Group PPprh \\
\hline \multicolumn{6}{|l|}{ Treatment } \\
\hline Progesterone & - & - & + & - & + \\
\hline LH-RH & - & - & - & + & + \\
\hline No. of ewes & 10 & 10 & 10 & 15 & 15 \\
\hline \multicolumn{6}{|l|}{ No. of ewes showing oestrus } \\
\hline < Day 24 (Category i) & 10 & 0 & 0 & 2 & .7 \\
\hline$>$ Day 24 (Category ii) & 0 & 9 & 9 & 12 & 8 \\
\hline \multicolumn{6}{|l|}{ Day of first detected oestrus } \\
\hline Category (i) & $20.5 \pm 1.4$ & & & $21 \cdot 5 \pm 1 \cdot 5$ & $20.6 \pm 0.75$ \\
\hline Category (ii) & 二 & $45 \pm 4 \cdot 4$ & $47 \cdot 1 \pm 2.6$ & $49.2 \pm 3.7$ & $38.4 \pm 0.78$ \\
\hline \multicolumn{6}{|l|}{ No. of oestrous periods } \\
\hline Category (i) & $4 \cdot 1 \pm 0 \cdot 2$ & & & $4 \cdot 0 \pm 0$ & $3.6 \pm 0.2$ \\
\hline Category (ii) & 二 & $2 \cdot 3 \pm 0.4$ & $2.0 \pm 0.33$ & $2 \cdot 2 \pm 0.27$ & $2.8 \pm 0.16$ \\
\hline $\begin{array}{l}\text { Interval from parturition to first } \\
\text { observed oestrus }\end{array}$ & - & $65 \cdot 2 \pm 4 \cdot 6$ & $68 \cdot 3 \pm 2 \cdot 7$ & $66 \cdot 2 \pm 4 \cdot 2$ & $51 \cdot 1 \pm 2 \cdot 4$ \\
\hline
\end{tabular}

Values are mean \pm s.e.m.

Plasma LH surges were detected in 11/15 Group PPprh ewes and in 11/15 Group PPrh ewes. The onset of plasma LH surges, the duration of the surges and the peak plasma LH concentrations were similar $(P>0.05)$ to those in the cyclic ewes (Group Cv) (Table 2).

After the LH surge progesterone was detected $(>0 \cdot 1 \mathrm{ng} / \mathrm{ml})$ in the plasma of $9 / 11$ Group PPprh ewes and in 10/11 Group PPrh ewes (Table 2). The period over which plasma progesterone was detectable was similar $(P>0.05)$ for ewes in Groups $\mathrm{Cv}$ and PPprh; this period was shorter $(\mathrm{P}<$ $0 \cdot 01, t=3.4)$ in Group PPrh ewes than in Group Cv ewes. The correlations between the duration of increased plasma LH concentrations before the plasma LH surge and the duration of the subsequent luteal phase in Groups Cv, PPrh and PPprh, and for the pooled values $(r=-0 \cdot 28$, $-0.09,0.4,-0.06)$ were not significant $(P>0.05)$. The mean and maximum concentrations of plasma progesterone were similar $(P>0.05)$ for ewes in Groups PPrh and PPprh and in cyclic ewes. After the decline in plasma progesterone concentrations oestrus and normal oestrous cycles occurred more often $\left(P<0.05, \chi^{2}=4.2\right)$ in Group PPprh (6/9) than in Group PPrh $(2 / 10)$ ewes. The plasma progesterone concentrations in the 2 Group PPv ewes were still elevated at the time of the last blood sample (Day 23). Plasma progesterone was detected in only 1 ewe (Group Cv) in which an LH surge was not detected. 
Table 2. Plasma LH surges (plasma $\mathrm{LH}>10 \mathrm{ng} / \mathrm{ml}$ for $>6 \mathrm{~h}$ ) and subsequent plasma progesterone in acyclic post-partum ewes and in control cyclic ewes

\begin{tabular}{|c|c|c|c|c|c|}
\hline & \multirow{2}{*}{$\frac{\text { Cyclic ewes }}{\text { Group } \mathrm{Cr}}$} & \multicolumn{4}{|c|}{ Post-partum ewes } \\
\hline & & Group PPv & Group PPp & Group PPrh & Group PPprh \\
\hline \multicolumn{6}{|l|}{ Treatment } \\
\hline Progesterone & - & - & + & - & + \\
\hline LH-RH & - & - & - & + & + \\
\hline No. of ewes & 10 & 10 & 10 & 15 & 15 \\
\hline No. showing LH surges & 9 & 2 & 0 & 11 & 11 \\
\hline Onset of LH surge (h)* & $74.4 \pm 3.8$ & $33 \cdot 0 \pm 18 \cdot 0$ & & $71 \cdot 1 \pm 2 \cdot 3$ & $66 \cdot 2 \pm 2 \cdot 3$ \\
\hline Duration of plasma LH surge (h) & $9.8 \pm 1.5$ & $10.5 \pm 1.5$ & & $8.5 \pm 0.9$ & $8 \cdot 4 \pm 0.5$ \\
\hline Peak plasma $\mathrm{LH}$ conc. (ng/ml) & $86.0 \pm 6.4$ & $91 \cdot 0 \pm 11 \cdot 1$ & & $88.5 \pm 13.1$ & $115.0 \pm 11.0$ \\
\hline $\begin{array}{l}\text { No. of ewes with detectable plasma } \\
\text { progesterone }(>0.1 \mathrm{ng} / \mathrm{ml}) \text { within } \\
7 \text { days after the plasma LH surge }\end{array}$ & $1 \overline{0}$ & $\overline{2}$ & 0 & $\overline{10}$ & $\overline{9}$ \\
\hline \multicolumn{6}{|l|}{$\begin{array}{l}\text { Period (days) of detectable } \\
\text { progesterone }(>0.1 \mathrm{ng} / \mathrm{ml})\end{array}$} \\
\hline Range & $10-17$ & $3-13$ & & $8-12$ & $10-17$ \\
\hline Mean & $11 \cdot 7 \pm 0.5$ & & & $9 \cdot 6 \pm 0.4$ & $12 \cdot 2 \pm 0 \cdot 8$ \\
\hline \multicolumn{6}{|l|}{ Distribution } \\
\hline Days & $10,11,12,15,17$ & & & $8,10,12$ & $10,12,17$ \\
\hline No. ewes & $2,1,5,1,1$ & & & $3,6,1$ & $4,4,1$ \\
\hline \multicolumn{6}{|l|}{ Plasma progesterone conc. $(\mathrm{ng} / \mathrm{ml}) \dagger$} \\
\hline Mean $\ddagger$ & $2.0 \pm 0.2$ & $2 \cdot 4 \pm 1 \cdot 1$ & & $1.7 \pm 0.2$ & $1.5 \pm 0.2$ \\
\hline Peak (mean) & $3 \cdot 1 \pm 0.4$ & $3.4 \pm 1.5$ & & $2.7 \pm 0.3$ & $2.4 \pm 0.2$ \\
\hline
\end{tabular}

Values are mean \pm s.e.m.

* Time after start of treatment with LH-RH or vehicle.

$\dagger$ Ewes with no detectable progesterone excluded from calculations.

$\ddagger$ Of the mean concentrations for each ewe.

\section{Discussion}

The results of this study indicate that ovarian acyclicity in ewes post partum can reflect inadequate pulsatile release of $\mathrm{LH}-\mathrm{RH}$ from the hypothalamus. The administration of $\mathrm{LH}-\mathrm{RH}$ in a pulsatile regimen to acyclic post-partum ewes resulted in most ewes having plasma LH surges, and subsequent luteal function similar to that in cyclic ewes. The failure of LH-RH treatment to induce normal luteal function in post-partum ewes in the previous study (Wright et al., 1983b) was probably due to an inappropriate pulsatile treatment regimen ( $100 \mathrm{ng}$ i.v. every hour for $48 \mathrm{~h}$ ). This regimen resulted in mean plasma LH concentrations greater than those associated with preovulatory follicular development in cyclic ewes. These two studies with post-partum ewes indicate that the formation of a properly functional corpus luteum requires a duration and pattern of preovulatory LH stimulation of the ovary similar to that occurring in cyclic ewes, from the time of luteolysis to the start of the plasma $\mathrm{LH}$ surge. The duration of $\mathrm{LH}$ stimulation associated with $\mathrm{LH}$ $\mathrm{RH}$ treatment in this study $(66.2 \mathrm{~h})$ was associated with normal luteal function and was similar to the duration of preovulatory LH stimulation of the ovary in control cyclic ewes. The shorter duration $(30.9 \mathrm{~h})$ of LH stimulation achieved in the previous study (Wright et al., 1983b) was associated with deficient luteal function.

It is possible that the difference in times of onset of the LH surge in this and the previous study reflects differences between the ewes and not differences in treatment regimens, since a direct comparison between treatment regimens was not made in the one experiment. This is unlikely, however, since the two studies, although performed in different years, used similar ewes from the same flock, in similar body condition, at similar stages post partum (19-26, 26-30 days), at the same time of the year. 
Studies of seasonally anoestrous ewes also indicate that normal luteal function requires an adequate period of LH stimulation of the ovary before the LH surge. This LH stimulation can be achieved by the pulsatile administration of $\mathrm{LH}$ in a frequency regimen the same as used for $\mathrm{LH}-\mathrm{RH}$ in this study (McNeilly, O'Connell \& Baird, 1982), or by the pulsatile administration of LH-RH to ewes pretreated with progesterone (McLeod et al., 1982). In the latter study, progesterone pretreatment delayed the onset of the LH surge and normal luteal function resulted. In ewes not pretreated with progesterone the period of increased plasma LH concentrations before the LH surge was shorter, and subsequent luteal function was deficient. In the present study, the failure of progesterone pretreatment to delay the LH surge suggests that there is a limited period after the onset of LH-RH treatment over which progesterone has this delaying effect, and that the LH surges induced in this study occurred outside this period. This is supported by the observations that in seasonally anoestrous ewes progesterone pretreatment ( 3 implants) delayed $\mathrm{LH}$ surges to only about $34 \mathrm{~h}$ after the onset of LH-RH treatment (McLeod et al., 1982), and in the present study LH surges occurred around 71 and $66 \mathrm{~h}$ after the onset of LH-RH treatment. The reason for improved luteal function and the earlier onset of ovarian cyclicity associated with progesterone pretreatment in $\mathrm{LH}$ RH-treated ewes in this study is unclear. The findings indicate that progesterone has effects on the hypothalamic-pituitary-ovarian axis not mediated simply by delaying the LH surge.

The failure of a proportion (27\%) of LH-RH-treated ewes (Groups PPprh and PPrh) to show an LH surge and subsequent normal luteal function could reflect the lack of stimulatory effect of oestrogen (oestrogen positive feedback) on LH release, which has been demonstrated using exogenous oestradiol in post-partum ewes (Wright et al., 1980). Failure to show an LH surge could also reflect inadequate responsiveness of the ovary to $\mathrm{LH}$ resulting in inadequate oestrogen production. It is unlikely to reflect inadequate pituitary responsiveness to LH-RH (Wright et al., 1980) since in that study pituitary responsiveness was similar in ewes showing or not showing LH surges.

Although the results of this study are relevant to the understanding of the basis of post-partum anoestrus, they cannot be considered as a breakthrough in the breeding of post-partum ewes. Pulsatile treatment regimens are clearly impractical. The continuous administration of low doses of LH-RH to progesterone-pretreated seasonally anoestrous ewes induces fertile oestrus (Wright, Clarke \& Findlay, 1983a), and oestrus, ovulation and normal luteal function (McLeod et al., 1983). The administration of $\mathrm{LH}-\mathrm{RH}$ in a continuous mode could provide the basis of a practical method for the induction of fertile oestrus in post-partum ewes.

We thank Mrs A. Bartlett, Mrs C. Cocks, Mrs R. Jenner and Mr B. Doughton for skilled technical assistance; Mrs D. Heffernan and Mrs L. Magill for typing; NIH and Dr H. Papkoff for LH standards; and Hoechst A.G. West Germany for LH-RH. These studies were supported by a grant from the Australian Meat Research Committee.

\section{References}

Burger, H.G., Lee, V.W.K. \& Rennie, G.C. (1972) A generalised computer programme for the treatment of data for competitive protein binding assays including radioimmunoassays. J. Lab. Clin. Med. 80, 302-312.

Hossain, M.I., Lee, C.S., Clarke, I.J. \& O’Shea, J. (1979) Ovarian and luteal blood flow, and peripheral plasma progesterone levels, in cyclic guinea-pigs. J. Reprod. Fert. 57, 167-174.

McLeod, B.J., Haresign, W. \& Lamming, G.E. (1982) Response of seasonally anoestrous ewes to small-dose multiple injections of $\mathrm{GnRH}$ with and without progesterone pretreatment. J. Reprod. Fert. 65, 223-230.
McLeod, B.J., Haresign, W. \& Lamming, G.E. (1983) Induction of ovulation in seasonally anoestrous ewes by continuous infusion of low doses of GnRH. $J$. Reprod. Fert. 68, 489-495.

McNeilly, A.S., O'Connell, M. \& Baird, D.T. (1982) Induction of ovulation and normal luteal function by pulsed injections of luteinizing hormone in anestrous ewes. Endocrinology 110, 1292-1299.

Wright, P.J., Geytenbeek, P.E., Clarke, I.J. \& Findlay, J.K. (1980) Pituitary responsiveness to LH-RH, the occurrence of oestradiol-17 $\beta$-induced LH-positive feedback and the resumption of oestrous cycles in ewes post partum. J. Reprod. Fert. 60, 171-176. 
Wright, P.J., Geytenbeek, P.E., Clarke, I.J. \& Findlay, J.K. (1981) Evidence for a change in oestradiol negative feedback and LH pulse frequency in postpartum ewes. J. Reprod. Fert. 61, 97-102.

Wright, P.J., Clarke, I.J. \& Findlay, J.K. (1983a) The induction of fertile oestrus in seasonally anoestrous ewes using a continuous low dose administration of gonadotrophin releasing hormone. Aust. vet. J. 60 , 254-255.

Wright, P.J., Geytenbeek, P.E., Clarke, I.J. \& Findlay, J.K. (1983b) LH release and luteal function in postpartum acyclic ewes after the pulsatile administration of LH-RH. J. Reprod. Fert. 67, 257-262.

Received 29 April 1983 